\title{
Palladium-Catalyzed N-Arylation of 2-Aminothiazoles
}

\author{
Meredeth A. McGowan, Jaclyn L. Henderson, and Stephen L. Buchwald \\ Department of Chemistry, Massachusetts Institute of Technology, Cambridge, Massachusetts \\ 02139, United States
}

Stephen L. Buchwald: sbuchwal@mit.edu

\section{Abstract}

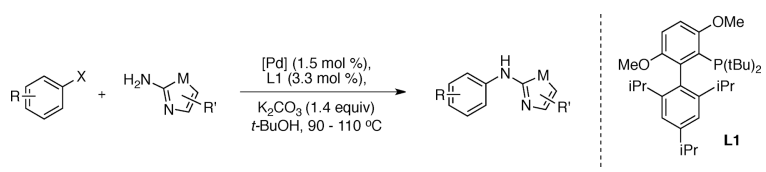

A method for the Pd-catalyzed coupling of 2-aminothiazole derivatives with aryl bromides and triflates is described. Significantly, for this class of nucleophiles, the coupling exhibits a broad substrate scope and proceeds with a reasonable catalyst loading. Furthermore, an interesting effect of acetic acid as an additive is uncovered that facilitates catalyst activation.

The 2-arylaminothiazole motif has appeared with increasing frequency throughout the medicinal chemistry literature over the past decade. It features prominently in compounds implicated for the treatment of cancer ${ }^{1}$ and psoriasis, ${ }^{2}$ and recently there have been several reports of 2-arylaminothiazole derivatives which show promising activity in assays targeting neurodegenerative disorders such as Alzheimer's disease ${ }^{3}$ (Figure 1). Typically, these compounds are synthesized by combining a mono-aryl thiourea and an ortho-bromo ketone to form the thiazole ring. However, as often SAR and lead optimization studies require the evaluation of multiple 2-aminoaryl groups, ${ }^{3,4}$ an efficient method for the direct arylation of 2-aminothiazole would significantly expedite the synthesis of analogs.

Palladium-catalyzed $\mathrm{C}-\mathrm{N}$ bond-forming methods are widely recognized as convenient and efficient means for obtaining $\mathrm{N}$-arylation products. ${ }^{5}$ However, primary amine derivatives of 5-membered heterocycles, particularly 2-aminoazoles, have historically been problematic substrates for Pd-catalyzed $\mathrm{N}$-arylation. While some methods for the $\mathrm{Pd}$-catalyzed coupling of these amines have been reported, ${ }^{5 \mathrm{a}, 6}$ they generally require high Pd loadings (2-18\%), long reaction times, and in most cases the use of an activated aryl electrophile. ${ }^{7}$ For example, the most comprehensive report to date is that of Yin, ${ }^{6}$ in which Xantphos and 2$8 \% \mathrm{Pd}$ are used to form select 2-arylaminothiazole derivatives in moderate to good yields. However, in the case of the unsubstituted 2-aminothiazole nucleophile, only extremely electron-poor aryl chloride electrophiles were reported as successful coupling partners. In the case of an electron-neutral aryl bromide, 2-aminobenzothiazole was required as the nucleophile to achieve successful coupling, along with the use of a relatively strong base $(\mathrm{NaO} t \mathrm{Bu})$.

In considering the differences between 2-aminothiazole derivatives and other readily coupled aryl amine nucleophiles, such as aniline and aminopyridine derivatives, we

Correspondence to: Stephen L. Buchwald, sbuchwal@mit . edu.

Supporting Information Available. Experimental procedures along with experimental and spectroscopic data for new compounds. This material is available free of charge via the Internet at http://pubs.acs.org. 
postulated that a key discrepancy might be their difference in pKa values. While anilines and aminopyridines have $\mathrm{pKa}$ values in the 25-30 range, the pKa values of 2-aminothiazole derivatives are closer to those of amides (generally in the 15-20 range) ${ }^{8}$ We therefore reasoned that conditions optimal for $\mathrm{N}$-arylation of amides might be more effective for this class of amine nucleophiles. In fact, 2-aminothiazole could indeed be coupled to $p$ bromoanisole in $60 \%$ yield $\left({ }^{1} \mathrm{H}\right.$ NMR $)$ using conditions reported previously by our laboratory as being optimal for the $\mathrm{N}$-arylation of amides $^{9}$ (Scheme 1 ).

Encouraged by this result, we briefly optimized the reaction conditions. We found $\mathrm{K}_{2} \mathrm{CO}_{3}$ to be optimal as the weak base, providing the product in higher yields than when $\mathrm{K}_{3} \mathrm{PO}_{4}$ was used, particularly in the case of aryl bromide electrophiles. ${ }^{10}$ Similar to our previous observations with amides, we found $\mathbf{L 1}$ (tBuBrettPhos) to be the ligand of choice, and that catalyst activation using the water activation protocol provided the most active catalyst, ${ }^{11}$ resulting in complete conversion to product in $2-3$ hours at $110{ }^{\circ} \mathrm{C} .{ }^{12} \mathrm{We}$ also found that, on a $1 \mathrm{mmol}$ scale, the use of $1.5 \mathrm{~mol} \% \mathrm{Pd}$ and a reaction concentration of $0.25 \mathrm{M}$ consistently provided high yields of 2-arylaminothiazoles.

With these optimal conditions in hand we evaluated the coupling of 2-aminothiazole with a variety of aryl bromides and triflates (Scheme 2). The desired 2-arylaminothiazole products were obtained in good yields for both electron-rich $(\mathbf{1 b}, \mathbf{1 d})$, electron-neutral $(\mathbf{1 a})$, and halogenated (1c) aryl bromides and triflates. Heterocyclic aryl triflates and bromides were also good substrates (1e, 1f). ${ }^{13}$ Unfortunately, aryl chloride electrophiles were incompatible with these general reaction conditions, succumbing to product inhibition at various conversions. ${ }^{14}$

Next, the generality of these conditions for the reaction of a range 2-aminothiazole-like nucleophiles was examined. Substituted 2-aminothiazoles (Scheme 3, 2a, 2b), as well as 2aminobenzothiazole (2d) and 2-amino-1,3,4-thiadiazole (2c), could all be arylated in good yields using the same reaction conditions (although the coupling to provide 2a required a slightly longer reaction time). Furthermore, other 2 -aminobenzazole-type nucleophiles such as 2-amino-1-methylbenzimidazole and 2-aminobenzoxazole also provided the corresponding $\mathrm{N}$-arylated products $\mathbf{2 e}$ and $\mathbf{2 f}$ in $90 \%$ and $89 \%$ yields, respectively.

In the case of more activated, electron-deficient aryl bromides and triflates, the formation of a significant amount of phenol was observed under these reaction conditions. ${ }^{14}$ In addition to decreasing the overall product yield, in some cases the phenol was difficult to separate from the desired product. Thus, we sought to identify a second set of coupling conditions that would effectively suppress phenol formation for activated substrates, reasoning that achieving catalyst activation under anhydrous conditions would be crucial. We found that we could suppress phenol formation by conducting the coupling at $90{ }^{\circ} \mathrm{C}$ in the presence of molecular sieves, and that a sufficiently active catalyst could be obtained by pre-heating $\mathbf{L} 1$ and $\mathrm{Pd}_{2} \mathrm{dba}_{3}$ at $110{ }^{\circ} \mathrm{C}$ for 2.5 minutes prior to introduction to the substrate mixture. ${ }^{15,16}$ This second set of conditions was effective for a wide range of activated electrophiles, including 4-bromochlorobenzene and 5-bromopyrimidine (3f and $\mathbf{3 g}$, Scheme 4). However, it should be noted that these conditions are uniquely suited to activated electrophiles; in the case of an electron-rich electrophile like 4-bromoanisole, product formation halts at 55\% conversion to 2-aminoarylthiazole $\mathbf{1 d}$.

We were interested in further exploring the dramatic increase in catalyst activity afforded by the water activation protocol for the coupling of 2-aminothiazoles, with the intention of potentially realizing an activation method that did not require a two-pot procedure. We originally postulated that water activation was simply the most effective means of obtaining the L1-ligated $\operatorname{Pd}(0)$ complex in the presence of substrates which have the potential for 
chelating $\operatorname{Pd}(0)$ and preventing ligand association, such as 2 -aminothiazoles. ${ }^{17}$ To test this hypothesis, the oxidative addition complex of $\mathrm{Pd}, \mathbf{L 1}$, and a simple aryl bromide was synthesized as previously described (Figure $2, \mathbf{A}) \cdot{ }^{18}$ Since this complex should lie on the active catalytic cycle, a reaction employing the complex as the Pd source should display maximum reactivity. Surprisingly, the rate of coupling of 4-bromotoluene and 2-

aminothiazole employing $\mathbf{A}$ as the Pd source (Figure 2, entry 2) was still drastically reduced as compared to the coupling which underwent the water activation protocol (Figure 2, entry 1). We thus suspected that an additive or byproduct associated with water activation might be responsible for the increased catalyst activity, and we systematically evaluated each (the phosphine oxide of $\mathbf{L} \mathbf{1}$, acetic acid, water ${ }^{11}$ in the presence of the oxidative addition complex. We found that, while the presence of water or the phosphine oxide of $\mathbf{L} \mathbf{1}$ had little effect on the reaction profile (Figure 2, entries 3 and 4), the presence of $2 \mathrm{~mol} \%$ of acetic acid dramatically enhanced reactivity (Figure 2, entry 5).

Having identified acetic acid as the source of increased catalyst activity, we sought to develop a one-pot procedure for the arylation of 2-aminothiazoles by adding acetic acid to the reaction mixture, along with the ligand and a $\mathrm{Pd}(0)$ source. We indeed found that by combining a catalytic amount of acetic acid $(3 \mathrm{~mol} \%)$ to the reaction mixture along with $\operatorname{Pd}_{2} \mathrm{dba}_{3}(0.75 \mathrm{~mol} \%), \mathrm{L} 1(3.3 \mathrm{~mol} \%)$, the substrates, base, and solvent in one pot, a reaction profile displaying activity similar to that of water activation was observed (Figure 2 , entry 6). To test the general applicability of this one-pot protocol, a few of the 2arylaminothiazole products from Schemes 2 and 3 were prepared, and comparable product yields were obtained (Scheme 5). The exact role of AcOH in the catalyst cycle, as well as its potential to effect other reactions catalyzed by L1-Pd complexes, is currently under investigation.

In summary, general protocols for the Pd-catalyzed $\mathrm{N}$-arylation of 2-aminothiazole derivatives with aryl triflates and bromides have been developed. Notably, through the use of $\mathbf{L 1}$ and proper catalyst activation, even electronrich aryl halide electrophiles can be coupled with 2-aminothiazoles with unprecedented efficiency. We expect this coupling method to find widespread use in the development of novel therapeutics.

\section{Supplementary Material}

Refer to Web version on PubMed Central for supplementary material.

\section{Acknowledgments}

We thank the National Institutes of Health (GM58160) for financial support of this project and for a postdoctoral fellowship to M. A. M. (F32GM097771). A Varian $500 \mathrm{MHz}$ spectrometer used for portions of this work was puchased with funds from the National Science Foundation (CHE-9808061).

\section{References}

1. (a) Das J, Chen P, Norris D, Padmanabha R, Lin J, Moquin RV, Shen Z, Cook LS, Doweyko AM, Pitt S, Pang S, Shen DR, Fang Q, de Fex HF, McIntyre KW, Shuster DJ, Gillooly KM, Behnia K, Schieven GL, Wityak J, Barrish JC. J. Med. Chem. 2006; 49:6819. [PubMed: 17154512] (b) Ghaemmaghami S, May BCH, Renslo AR, Prusiner SB. J. Virol. 2010; 84:3408. [PubMed: 20032192] (c) Borzilleri RM, Bhide RS, Barrish JC, D'Arienzo CJ, Derbin GM, Fargnoli J, Hunt JT, Jeyaseelan R, Kamath A, Kukral DW, Marathe P, Mortillo S, Qian L, Tokarski JS, Wautlet BS, Zheng X, Lombardo LJ. J. Med. Chem. 2006; 49:3766. [PubMed: 16789733]

2. Giltaire S, Herphelin F, Frankart A, Hérin M, Stoppie P, Poumay Y. Brit. J. of Dermatol. 2009; 160:505. [PubMed: 19120344] 
3. (a) Lubbers T, Flohr A, Jolidon S, David-Pierson P, Jacobsen H, Ozmen L, Baumann K. Bioorg. Med. Chem. Lett. 2011; 21:6554. [PubMed: 21924610] (b) Kounnas MZ, Danks AM, Cheng S, Tyree C, Ackerman E, Zhang X, Ahn K, Nguyen P, Comer D, Mao L, Yu C, Pleynet D, Digregorio PJ, Velicelebi G, Stauderman KA, Comer WT, Mobley WC, Li YM, Sisodia SS, Tanzi RE, Wagner SL. Neuron. 2010; 67:769. [PubMed: 20826309] (c) Gallardo-Godoy A, Gever J, Fife KL, Silber BM, Prusiner SB, Renslo AR. J. Med. Chem. 2011; 54:1010. [PubMed: 21247166]

4. (a) Lu Y, Li CM, Wang Z, Chen J, Mohler ML, Li W, Dalton JT, Miller DD. J. Med. Chem. 2011; 54:4678. [PubMed: 21557538] (b) Andersen CB, Wan Y, Chang JW, Riggs B, Lee C, Liu Y, Sessa F, Villa F, Kwiatkowski N, Suzuki M, Nallan L, Heald R, Musacchio A, Gray NS. ACS Chem. Biol. 2008; 3:180. [PubMed: 18307303]

5. For selected reviews and examples: (a) Maiti D, Fors BP, Henderson JL, Nakamura Y, Buchwald SL. Chem. Sci. 2011; 2:57. [PubMed: 22384311] (b) Surry DS, Buchwald SL. Angew. Chem. Int. Ed. 2008; 47:6338. (c) Marion N, Nolan SP. Acc. Chem. Res. 2008; 41:1440. [PubMed: 18774825] (d) Hartwig JF. Acc. Chem. Res. 2008; 41:1534. [PubMed: 18681463] (e) Tasler JM, Langa N. Adv. Synth. Catal. 2007; 349:2286. (f) Torborg C, Beller M. Adv. Synth. Catal. 2009; 351:3027. (g) Buchwald SL, Muager C, Mignani G, Scholz U. Adv. Synth. Catal. 2006; 348:23. (h) Kantchev EAB, O’Brien CJ, Organ MG. Angew. Chem. Int. Ed. 2007; 46:2768.

6. (a) Yin J, Zhao MM, Huffman MA, McNamara JM. Org. Lett. 2002; 4:3481. [PubMed: 12323049] (b) Tweedie SRS, James P II. Synlett. 2007:2331. (c) Jonckers THM, Maes BUW, LemiËre GLF, Dommisse R. Tetrahedron. 2001; 57:7027. (d) For an example in the context of a synthesis of a kinase inhibitor: Zhao M, Yin J, Huffman MA, McNamara JM. Tetrahedron. 2006; 62:1110.

7. A copper-based method has also been reported, though the use of aryl iodides and/or stoichiometric amounts of copper are generally required. See: Liu Y, Bai Y, Zhang J, Li Y, Jiao J, Qi X. Eur. J. Org. Chem. 2007; 2007:6084.

8. pKa ranges estimated from the Bordwell tables: Reich HJ. "Bordwell pKa Table". http:// www.chem.wisc.edu/areas/reich/pkatable/.

9. Fors BP, Dooleweerdt K, Zeng Q, Buchwald SL. Tetrahedron. 2009; 65:6576. [PubMed: 20740063]

10. See Supporting Information, Table S1.

11. Fors BP, Krattiger P, Strieter E, Buchwald SL. Org. Lett. 2008; 10:3505. [PubMed: 18620415]

12. See Supporting Information, Table S2 and Chart S1.

13. These reactions proceeded cleanly to product, though their extreme insolubility and crystalinity, especially in the case of $\mathbf{1 f}$, complicated isolation and resulted in decreased isolated yields.

14. Conversions and yields of up to $60 \%$ were observed with certain aryl chloride substrates, but others, such as $p$-chloroanisole, exhibited complete inhibition at $30 \%$ conversion. See Supporting Information for more details, Table S3 and Chart S2.

15. See Supporting Information, Table S4 for optimization.

16. We found the pre-heating to be necessary for reproducible yields. A similar protocol was reported in the use of biaryl phosphine ligands and $\mathrm{Pd}_{2} \mathrm{dba}_{3}$ for the selective $\mathrm{N}$-arylation of 1,2,3-triazoles: Ueda S, Su M, Buchwald SL. Angew. Chem. Int. Ed. 2011; 50:8944.

17. We have reported a series of palladacycle precatalysts which address this problem of catalyst activation but as of yet have not been able to form a stable precatalyst with ligand L1.

18. Maimone TJ, Milner PJ, Kinzel T, Zhang Y, Takase MK, Buchwald SL. J. Am. Chem. Soc. 2011; 133:18106. [PubMed: 21999801]

Org Lett. Author manuscript; available in PMC 2013 March 16. 
<smiles>Cc1nc(Nc2ncc(C(=O)Nc3c(C)cccc3Cl)s2)cc(N2CCN(CCO)CC2)n1</smiles>

Sprycel (dasatinib)

chronic myeloid leukemia (CML) Bristol-Myers Squibb<smiles>CC(C)[C@H](c1ccc(Nc2nc3ccccc3s2)cc1)n1cncn1</smiles>

Rambazole (talarozole) Psoriasis (Phase II Trials) Barrier Pharmaceuticals/Stiefel (GSK)<smiles>COc1cc(Nc2nc3c(s2)CCCC3c2ccccc2)ccc1-n1cnc(C)c1</smiles>

$\gamma$-secretase modulator Alzheimer's (30 mg/kg activity) F. Hoffman-La-Roche

Figure 1.

Biologically active 2-aminothiazoles. 
<smiles>Cc1ccc(Nc2nccs2)cc1</smiles>

\begin{tabular}{ccc}
\hline entry & Pd source & additive \\
\hline 1 & $\mathrm{Pd}(\mathrm{OAc})_{2}$ & $\mathrm{H}_{2} \mathrm{O}$ (water activation) \\
2 & A & none \\
3 & A & $\mathrm{H}_{2} \mathrm{O}(4 \mathrm{~mol} \%)$ \\
4 & A & $\mathrm{L} 1 \mathrm{P}=\mathrm{O}(2 \mathrm{~mol} \%)$ \\
5 & A & $\mathrm{AcOH}(2 \mathrm{~mol} \%)$ \\
6 & $\mathrm{Pd}_{2} \mathrm{dba}_{3}(0.75 \mathrm{~mol} \%)$ & $\mathrm{AcOH}(3 \mathrm{~mol} \%)$ \\
\hline
\end{tabular}

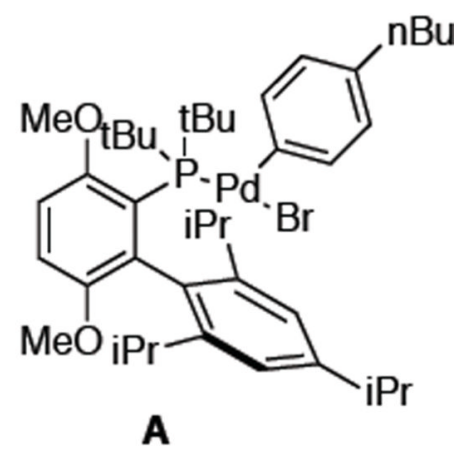

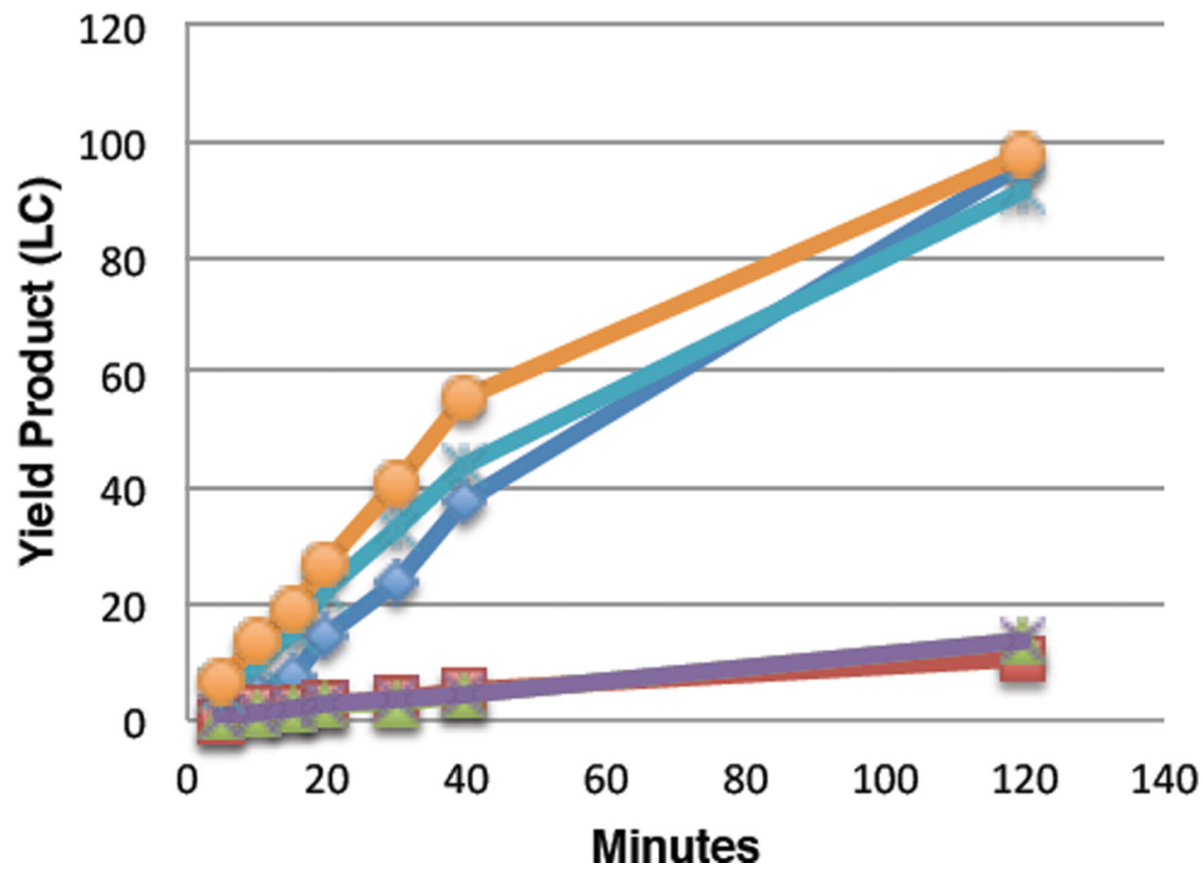

$\leadsto$ Entry 1

$-\square$ Entry 2

Figure 2.

Examination of Catalyst Activation 
<smiles>COc1ccc(Cl)cc1</smiles><smiles>NC(=O)Cc1cccs1</smiles>

(1.2 equiv)<smiles>Cc1ccc(Br)cc1</smiles><smiles>Nc1nccs1</smiles>

water activation:

$\mathrm{Pd}(\mathrm{OAc})_{2}(1.0 \mathrm{~mol} \%)$,

L1 $(2.2 \mathrm{~mol} \%)$, $\mathrm{H}_{2} \mathrm{O}(4 \mathrm{~mol} \%)$, $t$-BuOH [0.5 M], $110^{\circ} \mathrm{C}, 1.5 \mathrm{~h}$

water activation:

$\mathrm{Pd}(\mathrm{OAc})_{2}(1.0 \mathrm{~mol} \%)$, L1 $(2.2 \mathrm{~mol} \%)$, $\mathrm{H}_{2} \mathrm{O}(4 \mathrm{~mol} \%)$,

$\mathrm{K}_{3} \mathrm{PO}_{4}$ (1.4 equiv) $t$-BuOH [0.5 M], $110^{\circ} \mathrm{C}, 2 \mathrm{~h}$<smiles>COc1ccc(NC(=O)Cc2cccs2)cc1</smiles><smiles>COc1ccc(OC)c(C(C)C)c1-c1c(C(C)C)cc(C(C)C)cc1C(C)C</smiles>

Scheme 1.

Comparison of $\mathrm{N}$-arylation of amides and 2-aminothiazoles. 


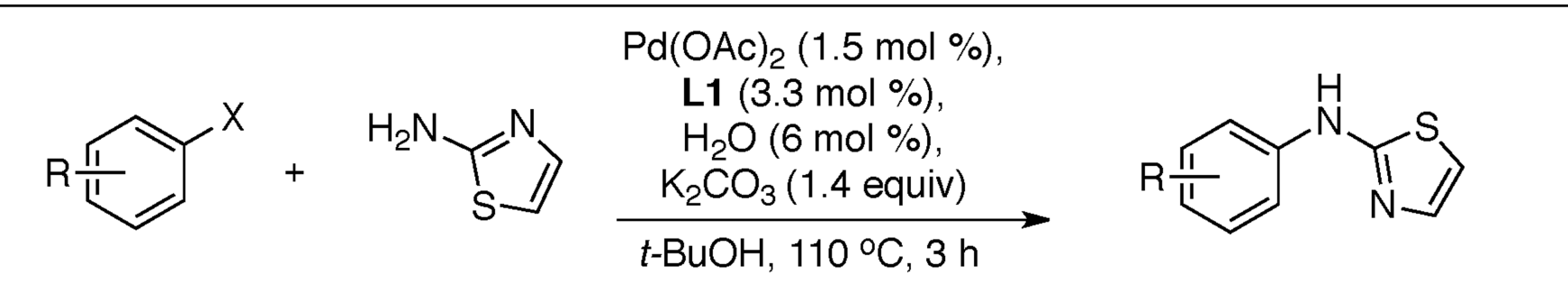<smiles>Cc1ccc(Nc2nccs2)cc1</smiles>

1 a $-83 \%(X=O T f)$<smiles>COc1ccc(Nc2nccs2)cc1</smiles>

$1 \mathrm{~d}-84 \%(X=\mathrm{Br})$<smiles>COc1ccc(Nc2nccs2)cc1OC</smiles>

1b $-79 \%(X=$ OTf $)$<smiles>Cc1ccc(Nc2nccs2)cn1</smiles>

$$
1 \mathbf{e}-72 \%(X=\text { OTf })
$$<smiles>Fc1cccc(Nc2nccs2)c1</smiles>

1c $-90 \%(X=$ OTf $)$<smiles>c1ccc(Nc2nccs2)nc1</smiles>

$$
1 f-65 \%(X=B r)
$$

Scheme 2.

Scope of 2-Aminothiazole Couplinga

aReaction conditions: ArX (1.0 mmol), 2-aminothiazole (1.0 mmol), Pd(OAc)2 (1.5 mol \%), $\mathbf{L 1}(3.3 \mathrm{~mol} \%), \mathrm{K}_{2} \mathrm{CO}_{3}(1.4 \mathrm{mmol}), t$ - $\mathrm{BuOH}(4 \mathrm{~mL} / \mathrm{mmol}), 110{ }^{\circ} \mathrm{C}, 3 \mathrm{~h}$; isolated yields, average of two runs. 


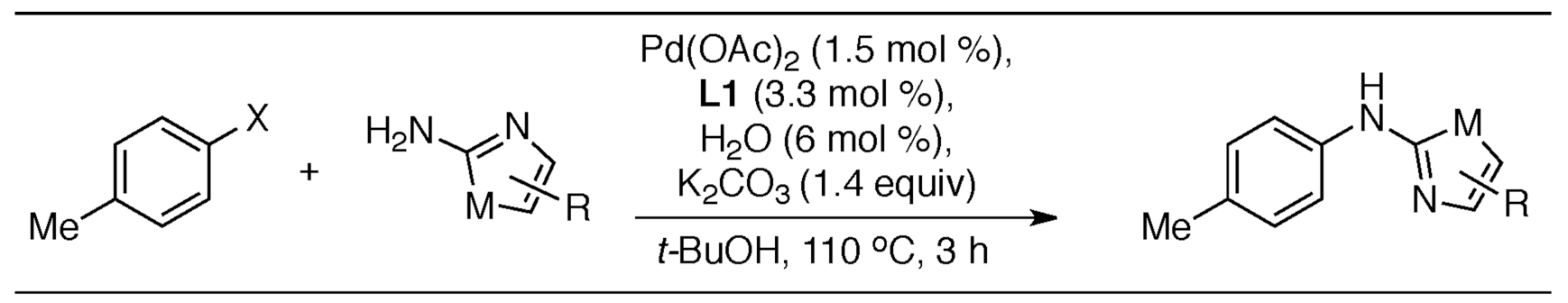<smiles>CCOC(=O)c1sc(Nc2ccc(C)cc2)nc1-c1ccccc1</smiles>

$\mathbf{2 a}-90 \%(X=B r)^{b}$<smiles>Cc1ccc(Nc2nc3ccccc3s2)cc1</smiles>

2d $-82 \%(X=O T f)$<smiles>Cc1ccc(Nc2nc(C(C)(C)C)cs2)cc1</smiles>

$2 \mathrm{~b}-86 \%(\mathrm{X}=\mathrm{Br})$<smiles>Cc1ccc(Nc2nc3ccccc3n2C)cc1</smiles>

$2 e-90 \%(X=B r)$<smiles>Cc1ccc(Nc2nncs2)cc1</smiles>

2c $-82 \%(X=$ OTf $)$<smiles>Cc1ccc(Nc2nc3ccccc3o2)cc1</smiles>

$2 \mathrm{f}-89 \%(\mathrm{X}=\mathrm{Br})$

Scheme 3.

Scope of 2-Aminothiazole Nucleophilesa

aReaction conditions: $\operatorname{ArX}(1.0 \mathrm{mmol}), 2$-aminoazole $(1.0 \mathrm{mmol}), \mathrm{Pd}(\mathrm{OAc})_{2}(1.5 \mathrm{~mol} \%)$,

$\mathbf{L 1}(3.3 \mathrm{~mol} \%), \mathrm{K}_{2} \mathrm{CO}_{3}(1.4 \mathrm{mmol}), t$ - $\mathrm{BuOH}(4 \mathrm{~mL} / \mathrm{mmol}), 110{ }^{\circ} \mathrm{C}, 3 \mathrm{~h}$; isolated yields, average of two runs. ${ }^{b} 5 \mathrm{~h}$ reaction time. 


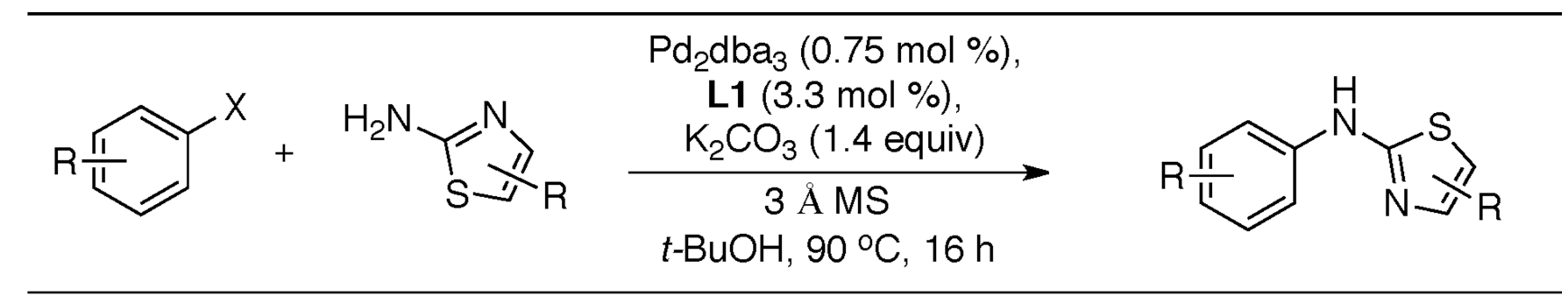<smiles>CC(C)(C)c1csc(Nc2ccc(C#N)cc2)n1</smiles>

3a $-95 \%(X=B r)$

$3 \mathbf{b}-93 \%(X=$ OTf $)$<smiles>COC(=O)c1ccc(Nc2nc3ccccc3s2)cc1</smiles>

$3 \mathbf{e}-80 \%(X=B r)$<smiles>N#Cc1ccc(Nc2nccs2)cc1</smiles>

3c $-67 \%(X=B r)$<smiles>Clc1ccc(Nc2nccs2)cc1</smiles>

3f $-91 \%(X=B r)$<smiles>CC(C)(C)c1csc(Nc2cccc(C#N)c2)n1</smiles>

3d $-91 \%(X=B r)$<smiles>CC(C)(C)c1csc(Nc2cncnc2)n1</smiles>

$\mathbf{3 g}-93 \%(X=\mathrm{Br})$

Scheme 4.

Scope for Electron-Deficient Electrophilesa

aReaction conditions: ArX (1.0 mmol), 2-aminoazole (1.0 mmol), $\mathrm{Pd}_{2} \mathrm{dba}_{3}(0.75 \mathrm{~mol} \%), \mathbf{L 1}$

(3.3 mol \%), $\mathrm{K}_{2} \mathrm{CO}_{3}$ (1.4 mmol), $3 \AA$ molecular sieves $(200 \mathrm{mg}), t$-BuOH $(4 \mathrm{~mL} / \mathrm{mmol}), 90$

${ }^{\circ} \mathrm{C}, 16 \mathrm{~h} .\left[\mathrm{Pd}_{2} \mathrm{dba}_{3}\right]$ and ligand were pre-mixed in $t-\mathrm{BuOH}$ at $110{ }^{\circ} \mathrm{C}$ for $2.5 \mathrm{~min}$; isolated yields, average of two runs. 


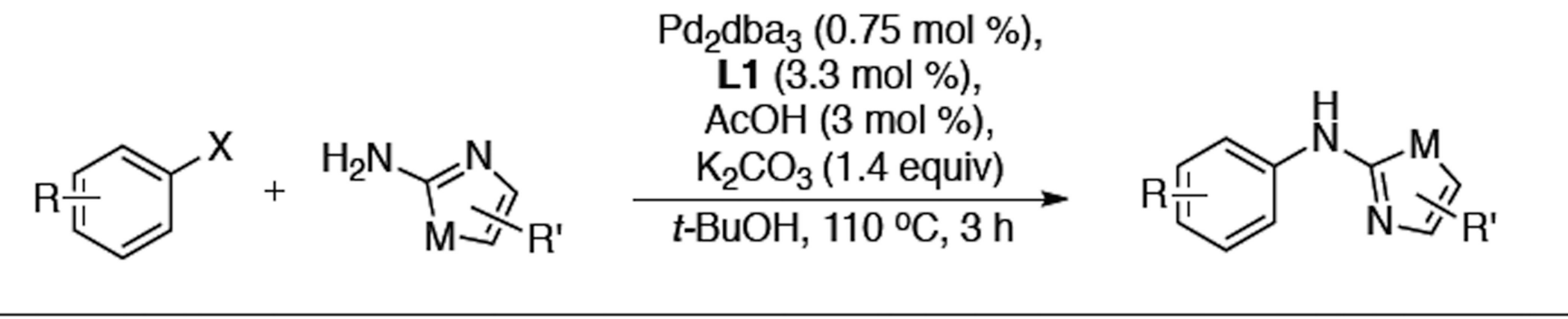<smiles>Cc1ccc(Nc2nccs2)cc1</smiles>

1a

$85 \%(X=$ OTf $)$<smiles>COc1ccc(Nc2nccs2)cc1</smiles>

$78 \%(\mathrm{X}=\mathrm{Br})$<smiles>CCOC(=O)c1sc(Nc2ccc(C)cc2)nc1-c1ccccc1</smiles>

$84 \%(\mathrm{X}=\mathrm{Br})^{\mathrm{b}}$

Scheme 5.

One-Pot Coupling of 2-Aminothiazolesa

aReaction conditions: ArX (1.0 mmol), 2-aminoazole (1.0 mmol), $\mathrm{Pd}_{2} \mathrm{dba}_{3}(0.75 \mathrm{~mol} \%), \mathbf{L 1}$ $(3.3 \mathrm{~mol} \%), \mathrm{AcOH}(2 \mathrm{~mol} \%), \mathrm{K}_{2} \mathrm{CO}_{3}(1.4 \mathrm{mmol}), t$ - BuOH $(4 \mathrm{~mL} / \mathrm{mmol}), 110{ }^{\circ} \mathrm{C}, 3 \mathrm{~h}$; isolated yields, average of two runs. ${ }^{\mathrm{b}} 5 \mathrm{~h}$ reaction time. 